\title{
STXBP2 Deficiency
}

National Cancer Institute

\section{Source}

National Cancer Institute. STXBP2 Deficiency. NCI Thesaurus. Code C126294.

A condition of decreased or absent presence of syntaxin-binding protein 2. Deficiency of this protein is associated with familial hemophagocytic lymphohistiocytosis type 5 . 